\title{
Strukturalisme Genetik Lucien Goldmann dalam Pengkajian Karya Sastra
}

\author{
Helaluddin \\ UIN Sultan Maulana Hasanuddin Banten
}

\begin{abstract}
Abstrak
Dalam perkembangan karya sastra, pengkajiannya sudah tidak hanya difokuskan pada unsur intrinsik saja tetapi juga sudah meluas ke unsur lain. Unsur lain tersebut merupakan unsurunsur yang berada di luar karya sastra. Hal ini didasarkan pada fakta bahwa sebuah karya sastra hadir tidak dimonopoli oleh daya imajinatif penulis semata tetapi ada faktor budaya dan sosial yang turut andil. Teori strukturalisme genetik muncul sebagai bentuk penolakan dari teori sebelumnya, strukturalisme murni. Artinya, dalam mengkaji sastra dengan teori ini tidak sebatas hanya membahas unsur intrinsik karya sastra tetapi ditambah dengan kajian kategori-kategori lain yang saling berkaitan. Dalam menopang teori strukturalisme genetik, Goldmann membangun seperangkat kategori yang saling berkaitan, yaitu fakta kemanusiaan, subjek kolektif, strukturasi, pandangan dunia pengarang, dan pemahaman-penjelasan.
\end{abstract}

Kata-kata kunci: karya sastra, strukturalisme genetik, fakta kemanusiaan, pandangan dunia pengarang, dan metode dialektik

\section{Pendahuluan}

Karya sastra muncul sebagai hasil inspirasi manusia dari daya imajinasi yang luar biasa. Imajinasi tersebut dituangkan dan diwujudkan dalam bentuk nyata berupa sebuah karya. Karya sastra tidak terbatas pada daya khayal atau imajinasi semata tetapi juga merupakan pencerminan dan pengaruh dari kehidupan nyata dari lingkungan penciptanya. Artinya, sebuah sastra ditulis dan dihasilkan oleh penulis sebagai anggota masyarakat di lingkungannya.

Pendefinisian karya sastra memang banyak terjadi perbedaan dari beberapa para ahli. Beberapa ahli memberikan definisi dan batasan tentang karya sastra yang berbeda dan saling bertentangan. Sastra juga ditafsirkan sebagai ekspresi yang 
bermakna luar biasa. Namun, para ahli sendiri tidak dapat memberikan penjelasan yang tepat dan pasti atau memberi batasan apa yang dimaksud dengan "ekspresi yang bermakna luar biasa" tersebut.

Kontroversi tentang definisi karya sastra pun meluas hingga ke tanah air. Paling mutakhir, pada era 2000-an dunia sastra Indonesia dihebohkan dengan kemunculan novel Langkar Pelangi karya Andrea Hirata. Novel ini mencatat sejarah sebagai novel yang paling banyak dibaca oleh penikmat sastra lokal bahkan hingga ke luar negeri. Kontroversi pun muncul tentang wujud Langkar Pelangi sebagai karya sastra ataukah sebagai catatan biografi penulis semata. Ada kubu masyarakat yang tidak menganggap Laskar Pelangi sebagai sebuah karya sastra karena isi yang diangkat adalah seputar perjalanan hidup sang penulisnya. Di sisi lain, ada kubu masyarakat yang tetap mengakui karya Andrea Hirata itu sebagai sebuah karya sastra karena karya tersebut terbentuk dari kekreatifan penulis sebagaimana halnya dalam karya sastra lain.

Karya sastra juga dapat didefinisikan sebagai bentuk cerminan dan cita-cita masyarakat tertentu. Hal itu terlihat dari gambaran karya sastra yang memperlihatkan kehidupan yang telah atau sedang terjadi, bahkan masa depan yang diharapkan oleh masyarakat. Kehadiran karya sastra di tengah-tengah masyarakat juga diterima sebagai salah satu realitas sosial budaya (Semi, 1990:1).

Dalam sejarah perkembangannya, karya sastra tidak hanya dianggap sebagai sebuah karya seni semata tetapi juga dianggap sebagai suatu karya kreatif. Kreatif dalam karya sastra meliputi banyak hal yang mencakup nilai budi, imajinasi, dan emosi yang dimanfaatkan sebagai konsumsi intelektual. Sebuah karya sastra yang diciptakan oleh pengarang diharapkan dapat menjadi kepuasan estetik dan intelektual bagi pembacanya.

Pengarang menuangkan refleksi kehidupan sosial atau realitas sosial sekelilingnya melalui karyanya. Pengarang berupaya mengajak pembaca untuk melihat, merasakan, dan menghayati hal-hal yang terjadi seperti sudut pandang yang 
digambarkannya. Adanya rasa haru, rasa sedih, dan rasa bahagia selalu menyertai pembaca setelah membaca karya sastra yang merupakan perubahan yang dialami dalam menyikapi kehidupan ini.

Pemahaman dan analisis karya sastra diperlukan dalam proses pembelajaran. Ada banyak metode dan teori-teori sastra yang digunakan sebagai pisau dalam menganalisis karya sastra. Dari zaman ke zaman, perkembangan teori sastra semakin menunjukkan ragamnya. Bermula dari teori yang hanya membedah karya sastra dari unsur intrinsik dan ekstrinsiknya sampai pada teori yang mengaitkan karya sastra dengan ranah sekitarnya. Ranah-ranah tersebut meliputi ranah psikologi, sosiologi, dan bahkan antropologi.

\section{Strukturalisme Genetik}

Strukturalisme genetik merupakan salah satu metode penelitian sastra yang populer digunakan dalam menganalisis karya sastra baik novel, cerpen, maupun puisi. Teori ini merupakan salah satu cabang sosiologi sastra yang memadukan antara struktur teks, konteks sosial, dan pandangan dunia pengarang (Yasa, 2012:28). Teori ini menekankan hubungan antara karya sastra dengan lingkungan sosialnya. Dalam masyarakat sesungguhnya manusia berhadapan dengan norma dan nilai, dalam karya sastra juga dicerminkan norma dan nilai yang secara sadar difokuskan dan diusahakan untuk dilaksanakan dalam masyarakat. Sastra juga melukiskan kecemasan, harapan dan aspirasi manusia. Oleh karena itu, kemungkinan karya sastra tersebut dapat dijadikan ukuran sosiologis yang paling efektif untuk mengukur tanggapan manusia terhadap kekuatan sosial.

Strukturalisme genetik dapat diidentifikasikan sebagai metode non-murni dan merupakan metode penentangan terhadap metode murni yang hanya menekankan penelitian sastra pada nilai-nilai intrinsik saja. Metode ini lebih jauh melangkah pada struktur sosial dan latar belakang karya sastra tersebut. Langkah-langkah inilah yang berhasil membawa strukturalisme genetik sangat dominan pada periode tertentu, 
dianggap sebagai teori yang berhasil memicu kegairahan analisis, baik di dunia Barat maupun di Indonesia.

Strukturalisme genetik ditemukan oleh Lucien Goldmann, seorang filsuf dan sosiolog Rumania-Perancis. Teori tersebut dikemukakan dalam bukunya yang berjudul The Hidden God: A study of Tragic Vision in the Penses of Pascal and the Tragedies of Racine, dalam bahasa Perancis terbit pertama kali tahun 1956. Strukturalisme genetik menurut Endraswara (2003:55) adalah salah satu metode penelitian sastra yang bersifat tidak murni yang merupakan bentuk penggabungan anatara struktural dengan metode penelitian sebelumnya. Menurut Goldmann dalam Faruk menyebutkan bahwa teorinya sebagai strukturalisme genetik yang artinya ia percaya bahwa karya sastra merupakan sebuah struktur. Akan tetapi, struktur itu bukanlah sesuatu yang statis, melainkan merupakan produk dari proses sejarah yang berlangsung, proses strukturasi dan destrukturasi yang hidup dan dihayati oleh masyarakat karya sastra yang bersangkutan.

Menurut Ratna (2004:123), secara definitif strukturalisme genetik adalah analisis struktur dengan memberikan perhatian pada asal-usul karya sastra. Secara ringkas berarti bahwa strukturalisme genetik sekaligus memberikan perhatian terhadap analisis instrinsik dan ekstrinsik. Meskipun demikian, sebagai teori yang telah teruji validitasnya, strukturalisme genetik masih ditopang oleh beberapa konsep terbaru yang tidak dimiliki oleh teori sosial lain, misalnya: simetri atau homologi, kelas-kelas sosial, subjek transindividual, dan pandangan dunia. Definis lain dikemukan oleh Rosyidi dkk (2010:201) yang menyatakan bahwa strukturalisme genetik adalah suatu metode penelitian sastra yang menekankan hubungan antara karya sastra dengan lingkungan sosialnya. Pada prinsipnya teori ini menganggap karya sastra tidak hanya struktur yang statis dan lahir dengan sendirinya tetapi juga merupakan hasil strukturasi pemikiran subjek penciptanya yang timbul akibat interaksi antara subjek dengan situasi sosial tertentu. 
Berdasarkan ketiga pembahan di atas dapat disimpulkan bahwa strukturalisme genetik adalah metode penelitian sastra yang menganalisis tidak hanya pada sisi intrinsiknya tetapi juga unsur-unsur pembangun yang berada di luar karya sastra. Unsur di luar karya sastra yang digali adalah aspek pengarangnya dan situasi sosial yang melatarbelakangi karya sastra tersebut dilahirkan.

Berdasarkan sejarahnya, teori strukturalisme genetik muncul sebagai tanggapan atau reaksi atas teori sebelumnya. Pada teori strukturalisme murni menganggap bahwa sebuah karya sastra dikaji hanya di ranah karya sastra itu sendiri tanpa melibatkan latar belakang sejarah di dalamnya. Berkaitan dengan masalah tersebut, Teeuw dikutip Endraswara (2003:55-56) menyatakan bahwa teori strukturalisme murni (strukturalisme klasik) kurang berhasil. Hal ini disebabkan oleh pemaknaan teks sastra yang mengabaikan pengarangnya sebagai pemberi makna akan berbahaya terhadap analisis karya sastra tersebut. Masih menurut Teeuw (1984:15), strukturalisme murni memiliki beberapa kelamahan, yaitu:

a. Analisis struktur karya sastranya belum menjangkau secara keseluruhan teori sastra dan justru tidak berdasarkan teori sastra yang lengkap dan tepat. Hal ini justru akan menimbulkan tanda dalam mengembangkan teori sastra yang dinilai sangat penting.

b. Karya sastra tidak dapat diteliti secara terasingdan terpisah, tetapi harus dipahami dalam rangka sistem sastra dengan latar belakang sejarah.

c. Adanya struktur yang objektif pada karya sastra makin diragukan, peranan pembaca sebagai pemberi makna dalam interpretasi karya sastra makin ditonjolkan dengan segala konsekuensinya untuk menganalisis struktur.

d. Analisis yang menekankan otonomi karya sastra juga dapat menghilangkan konteks dan fungsinya, sehingga karya sastra itu kehilangan relevansi sosialnya.

\section{Fakta Kemanusiaan}


Dalam menopang dan memperkuat teorinya, Goldmann menciptakan seperangkat teori yang memiliki saling keterkaitan antara satu dengan yang lain. Teori-teori yang yang saling bertautan itulah yang membentuk strukturalisme genetik. Teori yang maksud antara lain adalah fakta kemanusiaan, strukturasi, subjek kolektif, pandangan dunia pengarang, dan pemahaman-penjelasan.

Sebagai salah satu bagian dari strukturalisme genetik, fakta kemanusiaan dimaknai sebagai segala bentuk aktivitas manusia baik berupa aktivitas verbal maupun fisik yang berusaha dipahami oleh ilmu pengetahuan. Fakta kemanusiaan tersebut meliputi semua kegiatan sosial tertentu, kegiatan politik, budaya, seni, dan lain-lainnya. Secara tegas Faruk (2012:57) juga menjabarkan bahwa fakta kemanusiaan itu terdiri atas dua bagian. Fakta pertama adalah fakta individual yang merupakan hasil dari perilaku individu manusia baik yang berupa mimpi maupun tingkah laku. Fakta selanjutnya adalah fakta sosial, fakta ini berkaitan dengan peranan sejarah dan dampak hubungan sosial, ekonomi, politik antar-masyarakat.

\section{Konsep Pandangan Dunia Pengarang}

Seperti yang telah diuraikan pada bagian sebelumnya, strukturalisme genetik mengkaji karya sastra dengan melibatkan hal lain di luar teks sastra itu sendiri. Hal lain yang dimaksud adalah pandangan dunia pengarang. Menurut Goldmann dikutip Yasa (2012:30) pandangan dunia (world view) merupakan sesuatu pemahaman total terhadap dunia dengan segala permasalahan. Artinya, analisis ini dilakukan bukan pada ranah isi melainkan lebih pada struktur cerita. Pandangan dunia pengarang juga dapat didefinisikan sebagai wujud mediasi(kompromi) antara struktur masyarakat dan unsur karya sastra. Pandangan dunia hadir karena adanya kesadaran secara kolektif dari situasi masyarakat (strata sosial) yang ada. Artinya, pandangan ini lahir karena adanya antara subjek kolektif dengan situasi di sekitarnya.

Lebih lanjut, Goldmann juga menjabarkan bahwa pandangan dunia pengarang akan mencapai wujudnya yang nyata dalam karya sastra yang berkaitan dengan 
kelompok-kelompok sosial dan pandangan kelas sosial. Dalam mencapai pandangan dunia pengarang seperti yang diisyaratkan dalam teori strukturalisme genetik maka perlu dikaji secara lebih komprehensif pada struktur cerita bukan pada isi atau kontennya.

Secara rinci, Goldmann (dalam Endraswara, 2003:60) juga menyarankan agar karya sastra yang dianalisis dengan teori ini merupakan karya sastra tertentu, yaitu pada sastra besar. Tujuan pemilihan pada sastra besar ini adalah untuk menjembatani beberapa fakta estetik. Ada beberapa fakta estetik yang dimaksud di atas, yaitu: (1) hubungan pandangan dunia sebagai suatu realitas yang dialami pengarang dan (2) hubungan alam ciptaan dengan alat sastra seperti diksi, sintaksis, plot, dan gaya bahasa yang digunakan pengarang dalam ciptaannya. Goldmann juga memberikan dasar-dasar bagi peneliti strukturalisme genetik, yaitu:

1. Semua perilaku manusia mengarah pada hubungan rasionalitasnya (manusia selalu merespon terhadap lingkungannya)

2. Kelompok sosial mempunyai tendensi untuk menciptakan pola tertentu yang berbeda dari pola yang sudah ada

3. Perilaku manusia merupakan usaha yang dilakukan secara tetap menuju transendensi yang berupa aktivitas, transformasi, dan kualitas kegiatan dari semua aksi sosial dan sejarah

\section{Metode Dialektik}

Untuk memahami novel atau karya sastra lain, Goldmann mengembangkan suatu metode yang disebut dialektika. Goldmann memperkenalkan metode penelitian sastranya tersebut sebagai berikut.

1. Penelitian terhadap karya sastra dilihat sebagai suatu kesatuan,

2. Karaya sastra yang dianalisis hanyalah karya sastra yang mempunyai nilai sastra yang mengandung hubungan antara keragaman dan kesatuan dalam suatu keseluruhan yang padat 
3. Jika kesatuan telah ditemukan kemudian dianalisis hubungannya dengan latar belakang sosial. Sifat hubungan tersebut (a) yang berhubungan dengan latar belakang sosial adalah unsur kesatuan dan (b) latar belakang yang dimaksud adalah pandangan dunia sekelompok sosial, yang dilahirkan oleh pengarang sehingga hal tersebut dapat dikonkritkan (Yasa, 2012:31).

Teori dialektik menawarkan cara kerja dengan mengembangkan dua pasangan konsep berupa "keseluruhan-bagian" dan "pemahaman-penjelasan". Konsep "keseluruhan-bagian" mengacu pada pengertian bahwa setiap fakta atau ide perseorangan akan memiliki arti jika ditempatkan dalam keseluruhan. Keseluruhan tersebut hanya dapat dipahami dengan pengetahuan tentang bagian-bagian yang membangun keseluruhan itu. Konsep "pemahaman-penjelasan" mengandung pengertian bahwa pemahan merupakan usaha pendeskripsian struktur objek yang dikaji, sedang penjelasan merupakan usaha menggabungkan struktur objek tersebut ke dalam struktur yang lebih besar.

Menurut Goldmann (dikutip Endraswara, 2003:61) penelitian keseluruhansebagian membutuhkan bentuk-bentuk yang terjamin kehandalannya dalam memanfaatkan model yang disusun terbatas pada sejumlah unsur dan hubunganhubungannya. Dalam memulai penelitiannya, peneliti harus memahami bagian mana yang menjadi unsur dominan dalam karya sastra tersebut berdasarkan data empiriknya. Selanjutnya, peneliti memberikan sebuah penjelasan dari struktur internal sebagai bagian keseluruhan. Penjelasan struktur internal ini merupakan bagian terkecil dari pemahaman makna, sedangkan makna puncaknya adalah struktur secara menyeluruh.

\section{Metode Penelitian dalam Strukturalisme Genetik}

Metode yang akan digunakan dalam penelitian jenis ini adalah metode deskriptif kualitatif. Penggunaan metode ini bertujuan untuk mendapatkan gambaran 
yang jelas tentang objek yang dianalisisnya. Data yang dikumpulkan dalam penelitian ini berupa kata-kata bukan angka-angka.

Pendekatan penelitian yang digunakan adalah strukturalisme genetik adalah model dialektik.Teknik ini berbeda dengan positivistik, intuitif, biografi dan sebagainya. Model dialektik mengutamakan makna yang koheren. Prinsip dasar teknik analisis dialektik adalah adanya pengetahuan mengenai fakta-fakta kemanusiaan akan tetap abstrak apabila tidak dibuat konkret dengan mengintegrasikan ke dalam totalitas. Metode dialektik secara umum akan mengenalkan analisis "pemahaman-penjelasan". Pemahaman adalah usaha pendeskripsian struktur objek yang dipelajari, sedangkan penjelasan adalah usaha penemuan makna struktur itu dengan menggabungkannya ke dalam struktur yang lebih besar. Dengan kata lain, pemahaman merupakan langkah untuk mengidentifikasi bagian, dan penjelasan adalah langkah pemaknaan unsur bagian ke dalam unsur keseluruhan.

Secara garis besar, pelaksanaan analisis dialektik yang melingkar-lingkar mengikuti langkah-langkah: pertama, peneliti membangun sebuah model yang dianggap memberikan tingkat probabilitas tertentu atas dasar bagian. Kedua, ia melakukan pengecekan terhadap model itu dengan membandingkannya dengan keseluruhan (paragraf demi paragraf untuk kasus prosa, baris demi baris untuk kasus puisi, dan ucapan demi ucapan untuk drama). Hal ini dilakukan dengan cara menentukan: (a) sejauh mana setiap unit yang dianalisis digabungkan dalam hipotesis menyeluruh, (b) daftar elemen dan hubungan-hubungan baru yang tidak diperlengkapi dalam model semua, (c) frekuensi elemen-elemen dalam hubunganhubungan yang diperlengkapinya dalam model yang sudah diperiksa itu.

Secara sederhana, kerja peneliti strukturalisme genetik dapat diformulasikan dalam tiga langkah, yang meliputi:

1. Peneliti bermula dari kajian unsur intrinsik, baik secara parsial maupun dalam jalinan keseluruhannya. 
2. Mengkaji kehidupan sosial budaya pengarang, karena ia merupakan bagian dari komunitas tertentu.

3. Mengkaji latar belakang sosial dan sejarah yang turut mengkondisikan karya sastra saat diciptakan oleh pengarang.

Di sisi lain, teknik analisis data dalam penelitian ini berdasarkan pada langkahlangkah berikut:

a. Membaca dan memahami karya sastra yang akan dikaji baik novel, cerpen, roman, dan lain-lain.

b. Menyusun sinopsis karya sastra tersebut tersebut

c. Mengumpulkan data yang berkaitan dengan kehidupan sosial pengarang melalui berita-berita atau artikel baik di media cetak maupun media daring/online

d. Menganalisis unsur-unsur intrinsik novel tersebut

e. Mengkaji lingkungan sosial pengarang yang berhubungan dengan karya sastra tersebut

f. Menghubungkan antara lingkungan sosial pengarang dengan lingkungan sosial pada karya sastra (objek penelitian) untuk mengetahui seberapa besar pengaruh latar belakang sosial pengarang terhadap proses penciptaan karyanya

g. Menemukan tokoh-tokoh yang memiliki konflik paling dominan

h. Menemukan penyelesaian konflik yang diberikan oleh pengarang dalam karya sastra tersebut

i. Menarik simpulan

\section{Kesimpulan}

Teori strukturalisme genetik merupakan pecahan dari sosiologi sastra yang dikemukakan oleh sosiolog Perancis bernama Lucien Goldmann. Teori ini merupakan analisis struktural tak murni. Teori ini mucul karena adanya ketidaksepakatan para 
ahli pada saat itu tentang teori strukturalisme murni. Teori tersebut mengkaji karya sastra yang hanya dititikberatkan pada unsur-unsur instrinsik karya sastra dan mengesampingkan unsur yang lain. Dengan menggabungkan unsur instrinsik dan ekstrinsik karya sastra akan dirasakan lebih adil dan demokrat dalam menganalisis karya sastra. Pengintegrasian dua unsur yang berbeda tersebut paling tidak akan membentuk kelengkapan makna teks dalam memaknai karya sastra.

Strukturalisme genetik berusaha untuk memadu-padankan unsur-unsur karya sastra itu sendiri dengan unsur di luar karya sastra. Teori ini hadir dan dianggap sebagai penyempurna teori strukturalisme murni dengan memasukkan unsur genetik dalam memahami karya sastra. Awalnya teori ini diperkenalkan oleh Taine yang selanjutnya diteruskan oleh Goldmann. Menurut Goldmann, ada beberapa unsur penopang dalam teori ini, yaitu fakta kemanusiaan, konsep subjek kolektif, pandangan dunia pengarang, dan konsep pemahaman-penjelasan.

Berdasarkan konsep teori tersebut, strukturalisme genetik merupakan cikal bakal penelitian sastra dari ranah sosial atau sosiologi sastra. Namun kelebihan teori ini adalah kekonsistensian dalam mengedepankan pentingnya aspek struktur karya sastra. Kedua aspek struktur karya sastra tersebut, baik struktur dalam maupun struktur luar dipandang sama pentingnya dalam memahami karya sastra. Intinya, penelitian strukturalisme genetik mencakup tiga hal: (1) aspek instrinsik teks sastra, (2) latar belakang pengarang, dan (3) latar belakang sosial budaya serta sejarah masyarakatnya.

\section{Daftar Pustaka}

Endraswara, Suwardi. 2003. Metodologi Penelitian Sastra. Yogyakarta: CAPS.

Faruk. 2010. Pengantar Sosiologi Sastra. Yogyakarta: Pustaka Pelajar.

Jabrohim. 2001. Metodologi Penelitian Sastra. Yogyakarta: PT. Hanindita Graha Widia 
Noor, Rohinah M. 2011. Pendidikan Karakter Berbasis Sastra. Jogjakarta: Ar-ruz Media

Nurgiantoro, Burhan. 1994. Teori Pengkajian Fiksi. Jogjakarta: Gadjah Mada University Press

Ratna, Nyoman Kutha. 2004. Penelitian Sastra. Yogyakarta: Pustaka Pelajar.

Rosyidi, M. Ikhwan dkk. 2010. Analisis Teks Sastra. Yogyakarta: Graha Ilmu.

Siswanto, Wahyudi. 2013. Pengantar Teori Sastra. Malang: Aditya Media

Semi, Atar. 1990. Metode Penelitian Sastra. Bandung: Angkasa

Yasa, I Nyoman. 2012. Teori Sastra dan Penerapannya. Bandung: Karya Putra Darwati 